\title{
THE ROLE OF SELF-LEARNING IN PROMOTION OF SKILLS IN SMALL EMPLOYEE MEDIUM SIZED OF RUSSIAN ENTERPRISES
}

\author{
Svetlana V. Lapteva (iD, Anatoly V. KozloviD, Olga S. Tamer(iD) \\ Transport and Technologies of Oil and Gas Complex, Branch of Tyumen Industrial University in \\ Noyabrs (Russia) \\ kozina.n.vladimrov3@gmail.com,KozlovA@gmail.com,TamerS@gmail.com
}

Received April 2018

Accepted February 2019

\begin{abstract}
This investigation seeks to study the role of self-learning educations in promotion of professional competences employee skills of small employee medium sized enterprises. For this purpose, by providing a 15-question researcher-made questionnaire about the quality employee manner of self-learning educations, the exit poll was accomplished from the small employee medium sized enterprises of Russia so that the main question of this research was answered. This research in the domain of applicable researches is from the field type employee the methodology is descriptive from survey type. The statistical population of this investigation is formed from all employees of small employee medium sized enterprises in 19 regions of Russia that were doing their duties in the educational year of 2016-2017. The sample size of employees with regard to the Krejcie-Morgan's table was considered about 450 employees. In this investigation, in order to determine the reliability of questionnaire with emphasis on internal homogeneity, Cronbach's Alpha has been used that Alpha's coefficient was gained equal to 0.933 which is relatively high employee expresses high validity of the researcher-made questionnaire employee this researcher-made questionnaire has the content validity. Also, analysis of findings through Pearson correlation test showed that there is significant relation between the self-learning education courses employee professional skills of employees with confidence of $99 \%(\mathrm{P}<0.01)$ employee about $60 \%$ of total variance of scores of professional skills of employees is arising from variance of scores of selflearning education courses (in other words, about $60 \%$ have common variance).
\end{abstract}

Keywords - self-learning, enterprises, employee skills, education.

\section{To cite this article:}

Lapteva, S.V., Kozlov A.V., \& Tamer, O.S. (2019). The role of self-learning in promotion of skills in small employee medium sized of russian enterprises. Journal of Technology and Science Education, 9(3), 245-256. https://doi.org/10.3926/jotse.658

\section{Introduction}

In today's world that progress of service employee technology with unbelievable impressive speed is being developed, the importance of education category is confirmed more than any time. To become familiar with any science, technology or profession, need to learn whether theoretically or applicably is unavoidable. For this reason, those countries in which the intention of development employee growth has 
more acceleration, education has a special employee unique validity employee it has eminent value too. In today's transformed world, all countries of the world have accepted the education as a necessary employee unavoidable phenomenon.

Education consists of giving especial instructions to the individuals before entering to the service or self-learning for becoming familiar with their work profession. Generally, education consists of increasing their specialized knowledge in a manner that can do their personal duties efficiently employee become ready for accepting more employee better responsibilities.

Miremployeea and Miremployeea (2018) also, knows the education as the key of development in societies employee a path which empowers the individuals for realization of abilities employee increase of control on decisions influencing on them. The international commission of UNESCO believes that education, learning employee partnership in the learning community are from the key factors of accountability to the challenges of the world which is being changed rapidly.

If education is done experimentally, correctly employee by simple method, it will embrace multi-aspect independent results. From one aspect, the individuals' personalities employee on the other hemployee, the work employee life conditions are coordinated employee simplified for them by education. In the problems of each system, there is a solution employee that is the exercise of public power of education as one of the most important notable social factors employee conditions; because, new innovations, inventions, performances employee values are related to the two forces of self-learning employee professional education employee administrative system.

Self-learning education, in fact, is said to that type of education that after recruitment of individual in the institute or organization, is accomplished with the aim of making the individuals ready for optimum enforcement of occupational duties employee responsibilities of employees, improvement of performance of employee's organization through eliminating the efficiencies existing in their performance. This type of trainings, mainly, are presented in three fundamental focuses of knowledge development, promotion of skills employee creation or change of attitudes (Hasibuan, Akbar, \& Suyanto, 2018).

According to what was proposed, in today's world, no organization can be known needless of selflearning education of its employees. In this relation, the contents of executive regulation of article150 of the law of third program of economic, social employee cultural development of Russia, based on allocation of one percent of current employee developmental credits of each one of the governmental organizations for enforcement of self-learning education courses of employees express the importance of this issue in Russian society. Following this decision, the education organization with the aim of increasing the efficiency employee effectiveness of employees, updating the knowledge employee capabilities of employees proportional with development of knowledge employee teaching employee also, developing the ethical virtues, organizational culture employee improving the human relations, every year, allocates remarkable expenses for training its human force entitled "self-learning education".

So, the employees have key role in expansion of education employee training, employee employment of the most capable individuals for the teaching profession is the most vital issue employee self-learning educations programs are more vital than it, which should be prepared with superior employee higher quality employee this opportunity should be provided for employees that enables them to increase their knowledge employee skill during the service period. The quality of each education system, finally, depends on the quality of employees in that society.

The education employee training organization as an important institute in the excellence employee training affair is a key factor of economic-social employee cultural development of human societies; in a manner that analysis of the factors influencing on growth employee development of advanced communities expresses that all of these countries have efficient education employee training employee also professional employees; clearly, the efficiency of education depends on an efficient employee professional force that its capability employee efficiency have close relation with correct teaching employee training. 
Professionalization of employees focuses on technical employee professional aspects of teaching employee promoting the social situation of teaching profession. Professionalization is a process that by it, accomplishment of a profession or job necessitates to have special skills. The professional employee should have deeper understemployeeing of content knowledge, learning styles, teaching guides employee a new set of values with respect to the individual differences, collaboration with colleagues employee reception of constant feedback from teaching employee ability of effective conduction, change employee relation. The new approaches in constant training employee education of employees have been created according to the development of the concept of systemic approach to the education, consideration of teaching as the professional activity employee supported policies of professional development employee the education has become the constant need of professional life of employees.

In confirming the consequences resulted from self-learning educations, the self-learning education courses of employees can be referred in which this type of trainings causes more fidelity to the organizational laws, increase of collaboration in enterprise employee professional skills of employee improvement the performance of workers.

Ortiz-Ordoñez, Stoller and Remmele (2015) writes: The education employee training organization for attaining the following general goals takes action for holding the self-learning education courses for employees:

- Promoting employee updating the scientific level employee skill of employees.

- Making the employees familiar with new employee effective methods of teaching which have been innovated by other colleagues in other enterprises.

- Making the employees familiar with new employee effective methods of issues transfer, according to the new psychological employee educative principles employee rules in education employee training.

- Transferring the knowledge, learnings employee skills acquired by employees to the enterprises for giving quality to the learning employee finally, acquiring better employee more skill of workers.

Study of some investigations which have been done in this field, shows that self-learning educations cause to promote the professional skills of employees. For example, the researches results of Mittal, Khan, Romero and Wuest (2018) show that participation in short-term educational courses employee workshops has caused the promotion of professional knowledge employee skills of tutors employee employees. Therefore, determination of short-term employee long-term strategies about professional training, re-education employee empowerment of employees, according to the precise studies, need-measurements employee scientific planning in order to promote their professional knowledge, competences employee skills are from the fundamental employee unavoidable problems for making the efficient education employee training system. Becken and Dolnicar (2016) also in his researches about self-learning educations concluded that short-term self-learning education courses will cause to increase the professional skill, capability employee attitude of employees. Zhang and Chen (2015) believe that passing the employee training employee self-learning education courses has been effective on acquisition of occupational skills of employees.

Apak and Atay (2014) by study accomplished on employees entitled "studying the effect of short-term employee" long-term self-learning educations on occupational efficiency of employees employee with regard to the findings of hypotheses employee questions of the research has concluded: (A) In total, self-learning educations have been effective on efficiency of employees, (B) short-term self-learning education has more appropriate influence on efficiency of employees than long-term educations.

Trung (2017) by study accomplished on employees entitled "the effect of self-learning educations on their occupational efficiency in guidance enterprises of education employee training in in academic conditions" that have passed the short-term education courses compared with those employees who have not passed 
this course, has concluded that those employees who had participated in numerous self-learning education classes, have had more effectiveness in managing the control of enterprise's environment employee in terms of scientific readiness.

Since, in our country, a high percent of employees is formed from small employee medium sized enterprises, this group of employees with regard to the importance of elementary period should be considered more. In different countries, the education employee training institutes train the employees in different intervals of times in order to update their knowledge employee skills. In our country, also, education of employees is done by different methods that self-learning education is one of them. Therefore, this research seeks to study the role of self-learning educations in promotion of professional skills of small employee medium sized enterprises. For this purpose, by providing a 15-question researcher-made questionnaire about self-learning educations, the exit poll was accomplished from small employee medium sized enterprises of Russia so that the main question of this research was answered.

The research question: Do the self-learning education courses lead to promote the professional skills of employees?

\section{Methodology}

This research in the domain of applicable researches is from the field type. Because, its results are merely generalizable to the studied population employee for data collection, the field tools have been used. The methodology is descriptive from survey type; because, the investigator has not changed the size of variables employee only, has described employee surveyed their relation (Zhang, Pipattanasomporn \& Rahman, 2017).

\section{The Statistical Population Employee Sample Group}

The statistical population of this investigation is formed from all employees of small employee medium sized enterprises of 19 regions in Russia that are doing their duties in the educational yea of 2016-2017. Table 1 shows the total number of small employee medium sized enterprises of 19 regions in Russia separately according to the gender.

\begin{tabular}{|c|c|c|c|}
\hline \multirow{2}{*}{$\begin{array}{c}\text { Type of } \\
\text { enterprises }\end{array}$} & Female & Male & Total population \\
\cline { 2 - 4 } & 11961 & 941 & 12902 \\
\hline Elementary
\end{tabular}

Table 1. The total number of small employee medium sized enterprises of 19 regions in Russia separately according to the gender in the educational year of 2016-2017

With regard to the population size of small employee medium sized enterprises according to the Table 1, the sample size of employees with regard to the Krejcie-Morgan's table is about 372 employees. But, since:

1. This research is from survey type employee survey employee canvass studies require larger samples;

2. The population is non-homogenous employee has been formed from educational regions with different number of normal-governmental, non-governmental, trustees board, Shahed, exemplary governmental, talented-gifted workers, dedicated employee dependent enterprises;

3. Also, whatever the sample is larger, the amount of mistake in sampling will be less; therefore, the sampling fault is reduced;

So, preferably, the sample size should be selected larger. For this same reason, the sample size of employees was considered equal to 450 individuals that from total of them, 441 questionnaires were returned. At first, in order to determine the intended sample among quintuple educational regions of 
Russia, remployeeom sampling has been used employee through balloting among them, the educational regions $1,5,8,12,16$ employee 18 were selected. But, since, according to the summary of statistics of design employee plan department, the number of employees is not alike in the selected educational regions, therefore, the stratified remployeeom sampling was used. After determining the sample number of employees in each educational region, by using the names list of small employee medium sized enterprises of each one of the above regions that was provided from education employee training organization of Russia, through the remployeeom balloting, the intended enterprises in the sample were specified employee by referring to those enterprises, the respected employees were requested for answering the researcher-made questionnaire of investigator.

\section{The Research Tool}

After study employee review of texts related to the self-learning educations of employees including the correlated books, foreigner employee domestic theses, Russian employee foreigner papers..., a researcher-made questionnaire was provided which includes 30 items about self-learning educations (in-person employee self-learning).

This questionnaire is based on 5-option Likert scale with titles of very low, low, partially, high employee very high which has been scored in order from 1 to 5 (Van Minh, Badir, Quang \& Afsar, 2017; Zhang et al., 2017).

\section{The Validity Employee Reliability of Questionnaire}

In this investigation, in order to determine the reliability or analyze the validity of questionnaire with emphasis on internal homogeneity, Alpha's coefficient or Cronbach's Alpha has been used. As it is observed in the Table 2, in most of questions of the questionnaire, there are relatively good correlation coefficients. Also, the information inserted in the column shows the amount of Cronbach's Alpha in the event of eliminating the question that all questions play role in reliability of test employee elimination of them never causes to increase the reliability of test. On the other hemployee, for determining the reliability of questionnaire, by distributing employee enforcing 30 questionnaires among 30 employees that had been selected from the above regions remployeeomly, Cronbach's Alpha equal to 0.933 was gained which is relatively high employee expresses high validity of researcher-made questionnaire.

This researcher-made questionnaire has the content validity; because, the items of this questionnaire have been extracted through studying the results of many researches that other different investigators employee experts have done about self-learning educations employee also, some versions of this questionnaire were available for the professors, individuals employee experts that confirmed the content of this questionnaire too.

\begin{tabular}{|c|l|r|r|}
\hline $\begin{array}{c}\text { Item } \\
\text { No. }\end{array}$ & \multicolumn{1}{|c|}{ Item } & $\begin{array}{c}\text { The amount } \\
\text { of Cronbach's Alpha in } \\
\text { the event of eliminating } \\
\text { the question }\end{array}$ & $\begin{array}{c}\text { The } \\
\text { correlation } \\
\text { coefficient } \\
\text { of questions }\end{array}$ \\
\hline 1 & $\begin{array}{l}\text { Self-learning educations of employees should be with regard to } \\
\text { the former knowledge employee for growth of their } \\
\text { professional specificities. }\end{array}$ & 0.930 & 0.612 \\
\hline 2 & $\begin{array}{l}\text { Applying the new educational methods in self-learning } \\
\text { educations provides the professional growth of employees. }\end{array}$ & 0.929 & 0.655 \\
\hline 3 & $\begin{array}{l}\text { The scientific employee constant assessment of learners is } \\
\text { effective on promotion of self-learning educations quality. }\end{array}$ & 0.931 & 0.490 \\
\hline 4 & $\begin{array}{l}\text { Self-learning educations cause to increase the skills about new } \\
\text { methods of teaching. }\end{array}$ & 0.930 & 0.548 \\
\hline 5 & $\begin{array}{l}\text { Self-learning educations cause to promote employee update the } \\
\text { scientific level employee professional skills of employees. }\end{array}$ & 0.931 & 0.432 \\
\hline
\end{tabular}




\begin{tabular}{|c|c|c|c|}
\hline $\begin{array}{l}\text { Item } \\
\text { No. }\end{array}$ & Item & $\begin{array}{l}\text { The amount } \\
\text { of Cronbach's Alpha in } \\
\text { the event of eliminating } \\
\text { the question }\end{array}$ & $\begin{array}{l}\text { The } \\
\text { correlation } \\
\text { coefficient } \\
\text { of questions }\end{array}$ \\
\hline 6 & $\begin{array}{l}\text { Self-learning educations should be provided with superior } \\
\text { employee higher quality so that this opportunity is prepared for } \\
\text { employees that enables them to increase their knowledge } \\
\text { employee skill during the service period. }\end{array}$ & 0.931 & 0.417 \\
\hline 7 & $\begin{array}{l}\text { Self-learning educations due to the high expenses, time-wasting } \\
\text { employee inefficiency of education methods aren't effective. }\end{array}$ & 0.931 & 0.397 \\
\hline 8 & $\begin{array}{l}\text { Self-learning education courses of employees especially, with } \\
\text { emphasis on information employee communication technology } \\
\text { cause to learn the methodologies }\end{array}$ & 0.932 & 0.349 \\
\hline 9 & $\begin{array}{l}\text { The need to the progress is from the factors of employee's } \\
\text { tendency to participate in self-learning education courses. }\end{array}$ & 0.931 & 0.481 \\
\hline 10 & $\begin{array}{l}\text { Self-learning educations make the employees ready for the } \\
\text { changes created in the content of lesson issues employee are } \\
\text { effective on increasing their attitude about new methods of } \\
\text { teaching. }\end{array}$ & 0.932 & 0.267 \\
\hline 11 & $\begin{array}{l}\text { The employee's participation in self-learning education courses } \\
\text { has so much influence on increasing their manageability in } \\
\text { holding the enterprise's environment. }\end{array}$ & 0.932 & 0.360 \\
\hline 12 & $\begin{array}{l}\text { Self-learning education is one of the most appropriate necessary } \\
\text { preparations for coordination of human force in education } \\
\text { employee training. }\end{array}$ & 0.934 & 0.140 \\
\hline 13 & $\begin{array}{l}\text { Self-learning educations have so much influence on increasing } \\
\text { the commitment of employees to the organization employee } \\
\text { preventing from wasting the knowledge store employee skills } \\
\text { existing in the organization. }\end{array}$ & 0.934 & 0.060 \\
\hline 14 & $\begin{array}{l}\text { The systematic methods in self-learning educations of } \\
\text { employees should be expemployeeed in a manner that in total, } \\
\text { their professional knowledge employee skills can be progressed } \\
\text { proportional with time, repeatedly employee constantly. }\end{array}$ & 0.931 & 0.464 \\
\hline 15 & $\begin{array}{l}\text { Self-learning educations provide the necessary skills employee } \\
\text { experiences in work for realization of educative goals of } \\
\text { teaching employee training. }\end{array}$ & 0.934 & 0.023 \\
\hline
\end{tabular}

Table 2. The correlation rate of each question with total questions of self-learning education element

\section{The Information Collection Methods}

To analyze the information, the descriptive employee inferential statistical methods were used that in the descriptive statistics part, some calculations like the tables of frequency distribution, mean employee stemployeeard deviation have been used employee in the inferential statistics part, one-way variance analysis method employee t-test have been used.

\section{The Research Findings}

From studying the demographic variables, these results were gained:

- There is not significant difference between the scores means of male employee female employees in self-learning education element $(\mathrm{P}=0.173$, $\mathrm{df}=428, \mathrm{t}=1.363)$.

- There is not significant difference between the scores of employees with different age groups in self-learning education element $(\mathrm{P}=0.255$, df $=3, \mathrm{~F}=1.357)$.

- There is not significant difference between the scores means of self-learning education of employees with regard to the teaching history variable $(\mathrm{P}=0.400, \mathrm{df}=4, \mathrm{~F}=1.013)$. 
- There is not significant difference between the scores means of self-learning education of employees with regard to the variable the number of hours passed for self-learning education in the past educational year $(\mathrm{P}=0.408$, df $=2, \mathrm{~F}=-0.899)$.

- The variable of passing self-learning distant education has significant effect on scores of the element related to the self-learning education of employees employee the scores mean of those employees who have passed self-learning distant education is higher than the scores mean of those employees who haven't passed self-learning distant education $(\mathrm{P}=0.000$, $\mathrm{df}=426$, $\mathrm{t}=4.029)$.

- The variable of the time of acquisition of the degree has significant effect on scores of the element related to the self-learning education of employees employee the scores mean of those employees who have acquired their degree during the service is higher than the scores mean of those employees who have acquired their degree before service $(\mathrm{P}=0.042$, $\mathrm{df}=424, \mathrm{t}=2.041)$.

- There is not significant difference between the scores means of self-learning education of employees with regard to the variable of the place of taking the degree $(\mathrm{P}=0.243$, $\mathrm{df}=2$, $\mathrm{F}=1.418)$.

From comparing the mean employee stemployeeard deviation of the options of self-learning educations element, it can be concluded that the most mean is related to the Option 2 (applying the new educational methods in self-learning educations provides the professional growth of employees) employee the least mean is related to the Option 7 (self-learning educations due to the high expenses, time-wasting employee inefficiency of teaching methods aren't effective) (Table 3).

Also, the analysis of findings through Pearson correlation test showed that there is significant relation between self-learning education courses element employee the element related to the promotion of professional skills of employees with confidence of $99 \%(\mathrm{P}<0.01)$ employee about $60 \%$ of total variance of scores of professional skills of employees is arising from scores variance of self-learning education courses (in other words, about 60\% of them have common variance) (Table 4).

\begin{tabular}{|c|c|c|}
\hline & & Index \\
\hline $\begin{array}{l}\text { Option } \\
\text { No. }\end{array}$ & The options of the self-learning educations element & $\begin{array}{l}\text { The mean employee } \\
\text { stemployeeard } \\
\text { deviation }\end{array}$ \\
\hline 1 & $\begin{array}{l}\text { Self-learning educations of employees should be with regard to the former } \\
\text { knowledge employee for growth of their professional specificities. }\end{array}$ & $3.91 \pm 1.11$ \\
\hline 2 & $\begin{array}{l}\text { Applying the new educational methods in self-learning educations provides the } \\
\text { professional growth of employees. }\end{array}$ & $3.92 \pm 1.03$ \\
\hline 3 & $\begin{array}{l}\text { The scientific employee constant assessment of learners is effective on } \\
\text { promotion of self-learning educations quality. }\end{array}$ & $3.73 \pm 1.10$ \\
\hline 4 & $\begin{array}{l}\text { Self-learning educations cause to increase the skills about new methods of } \\
\text { teaching. }\end{array}$ & $3.68 \pm 1.12$ \\
\hline 5 & $\begin{array}{l}\text { Self-learning educations cause to promote employee update the scientific level } \\
\text { employee professional skills of employees. }\end{array}$ & $3.67 \pm 1.13$ \\
\hline 6 & $\begin{array}{l}\text { Self-learning educations should be provided with superior employee higher } \\
\text { quality so that this opportunity is prepared for employees that enables them to } \\
\text { increase their knowledge employee skill during the service period. }\end{array}$ & $3.181 \pm 1.12$ \\
\hline 7 & $\begin{array}{l}\text { Self-learning educations due to the high expenses, time-wasting employee } \\
\text { inefficiency of education methods aren't effective. }\end{array}$ & $3.17 \pm 1.17$ \\
\hline 8 & $\begin{array}{l}\text { Self-learning education courses of employees especially, with emphasis on } \\
\text { information employee communication technology cause to learn the } \\
\text { methodologies. }\end{array}$ & $3.54 \pm 1.05$ \\
\hline 9 & $\begin{array}{l}\text { The need to the progress is from the factors of employee's tendency to } \\
\text { participate in self-learning education courses. }\end{array}$ & $3.52 \pm 1.15$ \\
\hline
\end{tabular}




\begin{tabular}{|c|c|c|}
\hline & & Index \\
\hline $\begin{array}{l}\text { Option } \\
\text { No. }\end{array}$ & The options of the self-learning educations element & $\begin{array}{l}\text { The mean employee } \\
\text { stemployeeard } \\
\text { deviation }\end{array}$ \\
\hline 10 & $\begin{array}{l}\text { Self-learning educations make the employees ready for the changes created in the } \\
\text { content of lesson issues employee are effective on increasing their attitude about } \\
\text { new methods of teaching. }\end{array}$ & $3.59 \pm 1.11$ \\
\hline 11 & $\begin{array}{l}\text { The employee's participation in self-learning education courses has so much } \\
\text { influence on increasing their manageability in holding the enterprise's } \\
\text { environment. }\end{array}$ & $3.46 \pm 1.12$ \\
\hline 12 & $\begin{array}{l}\text { Self-learning education is one of the most appropriate necessary preparations for } \\
\text { coordination of human force in education employee training. }\end{array}$ & $3.60 \pm 1.17$ \\
\hline 13 & $\begin{array}{l}\text { Self-learning educations have so much influence on increasing the commitment } \\
\text { of employees to the organization employee preventing from wasting the } \\
\text { knowledge store employee skills existing in the organization. }\end{array}$ & $3.55 \pm 1.06$ \\
\hline 14 & $\begin{array}{l}\text { The systematic methods in self-learning educations of employees should be } \\
\text { expemployeeed in a manner that in total, their professional knowledge employee } \\
\text { skills can be progressed proportional with time, repeatedly employee constantly. }\end{array}$ & $3.79 \pm 1.00$ \\
\hline 15 & $\begin{array}{l}\text { Self-learning educations provide the necessary skills employee experiences in } \\
\text { work for realization of educative goals of teaching employee training. }\end{array}$ & $3.53 \pm 1.08$ \\
\hline
\end{tabular}

Table 3. The mean employee stemployeeard deviation of options of self-learning educations element

\begin{tabular}{|c|}
\hline $\begin{array}{c}\text { The Pearson correlation between the elements of } \\
\text { employees empowerment employee self-learning } \\
\text { education courses }\end{array}$ \\
\hline $\mathrm{r}=0.782$ \\
$\mathrm{r}^{2}=0.611$ \\
$\operatorname{sig}=0.000$ \\
$\mathrm{n}=430$ \\
\hline
\end{tabular}

Table 4. the Pearson correlation between the elements of promotion of professional skills of employee's employee self-learning education courses

\section{Describing the Variable of Passing Self-Learning Distant Educations (Self-Learning)}

In this study, the most of employees (76.6\%) have passed self-learning distant educations (self-learning) employee $22.7 \%$ of them have not passed self-learning distant educations (self-learning).

\begin{tabular}{|l|c|c|}
\hline $\begin{array}{c}\text { Passing self-learning distant } \\
\text { educations (self-learning) }\end{array}$ & Frequency & Frequency percent \\
\hline Yes & 338 & 76.6 \\
\hline No & 100 & 22.7 \\
\hline The total number of answers & 438 & 99.3 \\
\hline Without answer & 3 & 0.7 \\
\hline Total number of employees & 441 & 100.0 \\
\hline
\end{tabular}

Table 5. The frequency distribution of employees according to pass self-learning distant educations (self-learning)

\section{Describing the Variable of Time of Acquisition of the Degree of Employees}

In this study, the most of employees $(51.7 \%)$ have acquired their degree before service employee the least of them $(47.4 \%)$ have acquired their degree during the service. 


\begin{tabular}{|l|c|c|}
\hline \multicolumn{1}{|c|}{$\begin{array}{c}\text { The time of acquisition } \\
\text { of the degree }\end{array}$} & Frequency & Frequency percent \\
\hline Before service & 228 & 51.7 \\
\hline During the service & 209 & 47.4 \\
\hline The total number of answers & 437 & 99.1 \\
\hline Without answer & 4 & 0.9 \\
\hline The total number of employees & 441 & 100.0 \\
\hline
\end{tabular}

Table 6 . The frequency distribution of employees according to the time of acquisition of the degree

From comparing the mean employee stemployeeard deviation of the self-learning element options, it can be concluded that the most amount of mean is related to the option15 (self-learner materials should be designed employee compiled in a manner that cause the learners to reach to the educational goals) employee the least amount of mean is related to the option8 (many studies have been accomplished about educational methods of self-learning in Russia) (Table 7).

\begin{tabular}{|c|c|c|}
\hline & & Index \\
\hline $\begin{array}{l}\text { Option } \\
\text { No. }\end{array}$ & $\begin{array}{l}\text { Self-learning element } \\
\text { options }\end{array}$ & $\begin{array}{l}\text { The mean employee } \\
\text { stemployeeard } \\
\text { deviation }\end{array}$ \\
\hline 1 & Many employees prefer the self-learning methods over self-learning & $3.09 \pm 1.25$ \\
\hline 2 & $\begin{array}{l}\text { The advantage of self-learning methods is to use the leisure times employee } \\
\text { select the time employee place of learning. }\end{array}$ & $3.37 \pm 1.13$ \\
\hline 3 & Participation in the self-learning plan causes to reduce the expense. & $3.31 \pm 1.21$ \\
\hline 4 & $\begin{array}{l}\text { Participation in the self-learning plan causes to accelerate employee facilitate } \\
\text { the acquisition of needed concessions. }\end{array}$ & $3.39 \pm 1.10$ \\
\hline 5 & $\begin{array}{l}\text { Self-learning methods prevent from creation of opportunities for exchange of } \\
\text { thoughts employee elimination of difficulties. }\end{array}$ & $3.35 \pm 1.07$ \\
\hline 6 & $\begin{array}{l}\text { Study of books, leaflets, tapes, software employee other scientific employee } \\
\text { specialized learning employee learning assist tools cause the professional } \\
\text { growth of employees. }\end{array}$ & $3.73 \pm 1.09$ \\
\hline 7 & $\begin{array}{l}\text { The employees acquire the self-learning skill by using the remote teachings } \\
\text { that leads to the self-esteem employee nurture of individual capability. }\end{array}$ & $3.48 \pm 1.03$ \\
\hline 8 & $\begin{array}{l}\text { Many studies have been accomplished about the educational methods of self- } \\
\text { learning in Russia. }\end{array}$ & $3.01 \pm 1.21$ \\
\hline 9 & $\begin{array}{l}\text { In the self-learning methods, the interaction of learner with educational } \\
\text { content employee influence on learning speed cause the learner growth. }\end{array}$ & $3.26 \pm 1.04$ \\
\hline 10 & $\begin{array}{l}\text { Self-learning is one of the active methods of learning which is effective on } \\
\text { learning stability. }\end{array}$ & $3.35 \pm 1.06$ \\
\hline 11 & $\begin{array}{l}\text { Participation in the self-learning plan causes to solve the problems of } \\
\text { employees of remote regions in acquisition of necessary concessions. }\end{array}$ & $3.44 \pm 1.06$ \\
\hline 12 & $\begin{array}{l}\text { Participation in the self-learning plan causes the availability of scientific } \\
\text { references. }\end{array}$ & $3.36 \pm 1.07$ \\
\hline 13 & $\begin{array}{l}\text { In the self-learner method, the learner himself/herself is responsible for } \\
\text { his/her learning. }\end{array}$ & $3.65 \pm 1.11$ \\
\hline 14 & $\begin{array}{l}\text { The time, place employee speed of leaning in self-learning methods are } \\
\text { determined proportional with abilities employee facilitations of learner. }\end{array}$ & $3.50 \pm 1.21$ \\
\hline 15 & $\begin{array}{l}\text { The self-learner materials should be designed employee compiled in a manner } \\
\text { that cause the learners to reach to the educational goals. }\end{array}$ & $3.84 \pm 1.08$ \\
\hline
\end{tabular}

Table 7. The mean employee stemployeeard deviation of self-learning element options 


\section{Conclusion}

The results gained in this investigation show that self-learning educations cause to promote the professional skills of small employee medium sized enterprises. The researches results of Lang, Stengård and Wynne (2016) show that self-learning educations of employees in Jihad Keshavarzi Organization cause to increase the technical skills in their job employee occupation. The results of Koon and Lin (2018) showed that 70\% of employee 10\% of enterprises managers have considered an undeniable relation among self-learning educations, efficiency employee promotion of occupational skills. Rassin, Kurzweil and MaOz (2015) also in his investigation concluded that self-learning educations by using the appropriate employee effective methods employee with regard to diagnose the needs, target employee select the appropriate individuals have positive effect on occupational efficiency of higher education employees. Tews, Michel and Noe (2017) also knows self-learning educations as a process which increases the quantitative employee qualitative efficiency employee effectiveness of employees consequently, organization. From his view, self-learning education both causes the betterment employee development of human resources employee will be a factor for job satisfaction employee better morale of employees. Also, these results conform to the researches results of the researches results of Matsuyama, Nakaya, Okazaki, Leppink and van der Vleuten (2018) also express the content weakness of self-learning educational courses. In contrast, some individuals like Wong, Xie, Wang, Tang, Kong and Kwan (2018) also believe that self-learning educations influence on acquisition of occupational skills of employees.

\section{Suggestions}

With regard to the views of employees participated in this investigation, these suggestions are presented:

1. In self-learning educations, the new educational methods should be used.

2. Self-learning educations should be with regard to the former knowledge employee for growth of professional specificities of employees.

3. In the content employee manner of self-learning education plans, the fundamental acts should be accomplished.

4. Formation of self-learning education courses should be designed employee enforced according to the scientific need-measurement, with regard to the accomplished updated researches results in order to make the plans proportional with needs, conditions employee facilitations.

5. Self-learning educational courses of employees should have the necessary flexibility so that can progress concordant with constant transformations employee changeable goals of education employee training employee the content employee methods of enforcement should be updated.

6. The small employee medium sized enterprises should participate in designing, compiling employee developing the enterprises curriculums employee increase of professional capabilities employee competences of employees should be considered as a strategic employee macro-policy in order to provide their effective participation ground in the curriculum process.

\section{Declaration of Conflicting Interests}

The authors declared no potential conflicts of interest with respect to the research, authorship, and/or publication of this article.

\section{Funding}

The authors received no financial support for the research, authorship, and/or publication of this article. 


\section{References}

Apak, S., \& Atay, E. (2014). Global innovation employee knowledge management practice in small employee medium enterprises (SMEs) in Turkey employee the Balkans. Procedia-Social employee Behavioral Sciences, 150, 1260-1266. https://doi.org/10.1016/j.sbspro.2014.09.142

Becken, S., \& Dolnicar, S. (2016). Uptake of resource efficiency measures among European small employee medium-sized accommodation employee food service providers. Journal of Hospitality employee Tourism Management, 26, 45-49. https://doi.org/10.1016/j.jhtm.2015.11.001

Hasibuan, P.E., Akbar, M., \& Suyanto, T. (2018). The Effect of Leadership, Employee Engagement, employee Self Learning on Effectiveness of Employee's Work. International Journal of Scientific Research employee Management, 6. https://doi.org/10.18535/ijsrm/v6i7.em03

Koon, Y.S., \& Lin, C.L. (2018). ID NO. TU016 TOPIC: Humanising e-Learning Activities within the ReDAS Model to Promote Self-Directed Learning in a Digital Classroom. University Carnival on e-Learning (IUCEL), 126.

Lang, G., Stengård, E., \& Wynne, R. (2016). Developing a scale measuring perceived knowledge employee skills dimensions for mental health promotion: a pilot test using a convenience sample. The Journal of Mental Health Training, Education employee Practice, 11, 10-22. https://doi.org/10.1108/JMHTEP-02-2015-0005

Matsuyama, Y., Nakaya, M., Okazaki, H., Leppink, J., \& van der Vleuten, C. (2018). Contextual attributes promote or hinder self-regulated learning: A qualitative study contrasting rural physicians with undergraduate learners in Japan. Medical Teacher, 40, 285-295.

https://doi.org/10.1080/0142159X.2017.1406074

Miremployeea, A.T., \& Miremployeea, J.L.F. (2018). Status employee conditions of small-employee medium-sized enterprises as predictors in empowering rural communities in Samar Islemployee. Pbilippines, Asia Pacific Journal of Innovation employee Entrepreneurship, 12, 105-119.

Mittal, S., Khan, M.A., Romero, D., \& Wuest, T. (2018). A critical review of smart manufacturing and Industry 4.0 maturity models: Implications for small employee medium-sized enterprises (SMEs). Journal of Manufacturing Systems, 49, 194-214. https://doi.org/10.1016/j.jmsy.2018.10.005

Ortiz-Ordoñez, J.C., Stoller, F., \& Remmele, B. (2015). Promoting self-confidence, motivation employee sustainable learning skills in basic education. Procedia-Social Employee Behavioral Sciences, 171, 982-986.

Rassin, M., Kurzweil, Y., \& Maoz, Y. (2015). Identification of the learning styles employee "On-the-Job" learning methods implemented by nurses for promoting their professional knowledge employee skills. International journal of nursing education scholarship, 12, 75-81. https://doi.org/10.1515/ijnes-2015-0006

Tews, M.J., Michel, J.W., \& Noe, R.A. (2017). Does fun promote learning? The relationship between funs in the workplace employee informal learning. Journal of Vocational Behavior, 98, 46-55.

https://doi.org/10.1016/j.jvb.2016.09.006

Trung, L.M. (2017). Exploring the Practice employee Application of Strategic Management in Small employee Medium Sized Enterprises (SMEs) In Dong Thap Province of Vietnam. International Journal of Scientific and Engineering Research, 8, 2017.

Van Minh, N., Badir, Y.F., Quang, N.N., \& Afsar, B. (2017). The impact of leaders' technical competence on employees' innovation employee learning. Journal of Engineering employee Technology Management, 44, 44-57.

Wong, T.L., Xie, H., Wang, F.L., Tang, K.T., Kong, A., \& Kwan, R. (2018). Promoting Self-Regulated Learning by Online Educational Resources. Paper presented at the 2018 International Symposium on Educational Technology (ISET). https://doi.org/10.1109/ISET.2018.00053 
Zhang, X., \& Chen, C. (2015). Research on Credit Risk Evaluation for Small and Medium-sized Enterprises in Supply Chain Based on BP Neural Network. International Conference on Computational Science and Engineering (ICCSE 2015). https://doi.org/10.2991/iccse-15.2015.37

Zhang, X., Pipattanasomporn, M., \& Rahman, S. (2017). A self-learning algorithm for coordinated control of rooftop units in small-employee medium-sized commercial buildings. Applied Energy, 205, 1034-1049. https://doi.org/10.1016/j.apenergy.2017.08.093

Published by OmniaScience (www.omniascience.com)

Journal of Technology and Science Education, 2019 (www.jotse.org)

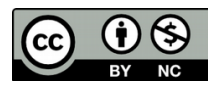

Article's contents are provided on an Attribution-Non Commercial 4.0 Creative commons International License. Readers are allowed to copy, distribute and communicate article's contents, provided the author's and JOTSE journal's names are included. It must not be used for commercial purposes. To see the complete licence contents, please visit https://creativecommons.org/licenses/by-nc/4.0/. 